\title{
The Obstacles to Decent Work for Migrants in Jordan: A Discussion with Alia Hindawi
}

\author{
Jennifer Gordon
}

\begin{abstract}
Alia Hindawi, Programme Manager for Jordan and Lebanon at the Business and Human Rights Resource Centre (BHRRC), is a longtime advocate for the rights of migrant and refugee workers in the Middle East. Born in Pakistan and raised in Jordan, Hindawi has worked for the International Organization for Migration and the International Labour Organization, as well as for the International Trade Union Confederation and the Jordanian Ministry of Planning and International Cooperation, among others. In this interview, she explains how the kafala (migrant sponsorship) system interacts with other formal and informal structures on the transnational, national, and individual level and contributes to the exploitation of migrant workers in Jordan, and recommends a set of reforms to address these issues.
\end{abstract}




\section{Introduction}

Migrant workers and refugees do many of the least desirable, lowest-paid jobs in Jordan, including in construction, agriculture, domestic work, and garment manufacturing. They work long hours and face dangerous conditions for minimal pay that may be delayed or denied to them. Many scholars and activists have focused on the kafala (sponsorship) system in Jordan and other countries in the Middle East as a critical source of migrant vulnerability, and Alia Hindawi agrees. But she argues that in order to grasp how and why migrants are exploited, one must also understand the interaction of that system with other formal laws, as well as informal practices on the transnational, national, and individual levels.

\section{The kafala system: Migrants without mobility}

Almost every nation around the world that issues visas for low-wage labour migrants ties the worker's right to work and reside in that country to a sponsoring employer. The kafala system, common throughout the Gulf, and also in place in Jordan and Lebanon, is no exception. ${ }^{2}$ The kafala system allows a migrant to work only for one sponsoring employer, and requires that the migrant leaves the country as soon as that relationship ends. Employers are not required to provide reasons for withdrawing their sponsorship. In Jordan, the kafala system applies to all non-Jordanian workers.

Hindawi notes that the extreme power imbalances in the kafala system create conditions that are ripe for forced labour. Migrants are subjugated by the kafeel. "The serious limitation on [migrants'] mobility alone," she notes, "makes it very difficult" for migrants to access their rights. A worker who leaves an abusive situation or is fired no longer has a valid work permit. "[I]f the work permit is revoked, the residency permit is revoked, and so [the migrant is] suddenly illegal in the country," running a real risk of being arrested.

\section{Labour protection in Jordan: Missing in action}

Hindawi emphasises, however, that the kafala system does not operate in a vacuum.

For one, it is essential to consider the interactions of the kafala system with other aspects of Jordanian law and policies that disadvantage migrants. For example, while the Jordanian Labour Code grants some labour protections to migrants and native workers alike (see below), it also includes official wage disparities between Jordanians and foreign workers. "You have a minimum wage for migrant garment workers, and then a different minimum wage for

\footnotetext{
${ }^{1}$ Daniel Costa and Philip Martin, “Temporary Labor Migration Programs: Governance, Migrant Worker Rights, and Recommendations for the U.N. Global Compact for Migration," website, Economic Policy Institute, August 2018, available at:

https://www.epi.org/publication/temporary-labor-migration-programs-governance-migrant-worker-rights-and-recom mendations-for-the-u-n-global-compact-for-migration/ [last accessed 26 August 2019]; Patti Lenard and Christine Straehle, "Temporary Labour Migration: Exploitation, Tool of Development, or Both?" Policy and Society, 2010, Vol. 29 (4), p. 283-294, at p. 289.

${ }^{2}$ In Jordan, the kafala system applies to all non-Jordanian workers, whereas in other countries, only specific nationalities are subjected to the kafala system. See, e.g., Elizabeth Frantz, "Jordan's Unfree Workforce: State-Sponsored Bonded Labour in the Arab Region," Journal of Development Studies, 2013, Vol. 49(8), p. 1072-1087, at p. 1077; Priyanka Motaparthy, "Understanding Kafala: An Archaic Law at Cross Purposes with Modern Development," Website, Migrant Rights, 2015, available at:

https://www.migrant-rights.org/2015/03/understanding-kafala-an-archaic-law-at-cross-purposes-with-modern-devel opment/ [last accessed 26 August 2019].
} 
Jordanians. The same discrimination applies in the construction sector. In fact, across the country, there is a different minimum wage for Jordanians and for [migrant] workers."

Hindawi notes that although Jordanian law does guarantee migrants certain labour protections, such as limitations on hours of work and the payment by the employer of work permit fees, among others. The lack of adequate policy mechanisms renders those rights very difficult to enforce. ${ }^{3}$ For example, the Ministry of Labour does not actively conduct inspections for violations of labour standards in migrant-heavy industries. ${ }^{4}$ Instead, most of its limited enforcement resources are steered towards finding migrants who work without a permit. This, Hindawi explains, "is a [...] serious problem." Jordan has passed labour laws that purport to cover migrant workers," but "what's the point if we are not enforcing the law?" When labour standards are not enforced, the kafala system puts the sponsor in a position to treat migrant workers in ways that violate Jordanian law and international human rights protections. A further factor that renders migrant workers vulnerable is the absence of empowered trade unions. For some sectors, the Jordanian government only recognises one official union, and unions have a weak presence among migrants in most industries. ${ }^{5}$

Moreover, without effective collective representation, a particular concern is the lack of an effective mechanism for individual redress through the courts. Because of the kafala system, migrants cannot remain in Jordan after leaving work or being fired. However, it is not possible to pursue a claim in court from abroad. Migrants who are deported thus have no way to bring a claim against a former employer to recover unpaid wages or pursue other violations of law.

Hindawi also reminds us that a number of transnational forces play a critical role in shaping the vulnerability of migrant workers.

One set of transnational actors omnipresent in labour migration are private labour broker companies, which recruit migrants in their home countries and connect them to formal work (with a permit) in Jordan. Hindawi notes that such brokers are notorious for illegally charging high fees, making false promises about the work migrants will do on arrival, and lending money at usurious rates to cover the costs of migration. As a result, when migrants arrive in Jordan, they are often deeply in debt, and must repay what they have borrowed before they will be able

\footnotetext{
${ }^{3}$ For an overview of Jordanian laws pertaining to migrant workers, see: International Labour Organization, "Migrant Domestic and Garment Workers In Jordan: A Baseline Analysis of Trafficking in Persons and Related Laws and Policies," Geneva, International Labour Office-Fundamental Principles and Rights at Work Branch (FUNDAMENTALS), 2017, available at: https:/www.ilo.org/wcmsp5/groups/public/---ed norm/---declaration/documents/publication/wcms 554812.pdf [last accessed 26 August 2019].

${ }^{4}$ The primary exception is in the garment export industry, where the Ministry of Labour collaborates with Better Work Jordan (a program of the International Labour Organization) to inspect factories for labour standards violations.

${ }^{5}$ One exception here is in the garment export industry, where the union has negotiated a contract that covers many migrant workers. See: International Labour Organization "Case Study: Collective Bargaining Agreements in Jordan's Garment Industry," Geneva, Better Work - International Labour Organisation \& International Finance Corporation, n.d., available at:

https://betterwork.org/global/wp-content/uploads/ILO-Better-Work Jordan-Case-Study LR Web.pdf [last accessed 26 August 2019].
} 
to send money home. ${ }^{6}$ The resulting sense of desperation leaves migrants reluctant to report abuse to the authorities, for fear that they will be fired by the kafeel and deported before they can begin to help their families back home.

To understand the obstacles migrants face in reclaiming their rights, Hindawi says that it is necessary to examine how the kafala system and other aspects of Jordanian law, as well as the role of labour brokers, play out in specific sectors. She offers the domestic work and construction sectors as two examples.

\section{Domestic workers: Multiple layers of vulnerability}

Migrant domestic workers face additional limitations on their freedom that mainly stem from employer practices. Hindawi points out that although the Jordanian law forbids employers from holding migrant domestic workers' passports, in reality, this practice is rather common. Similarly, employers are required to allow domestic workers to leave their home, but often they do not. "Many of the human rights infringements happen and continue because the employer does not allow the worker to leave the house, which means they're not able to tell other people if abuse occurs." When domestic workers are forced to work around the clock or without a rest day, are paid little or nothing at all, or suffer physical, sexual, or emotional abuse, they face an impossible choice: keep working under those conditions, or leave the job and face imprisonment and deportation.

Hindawi notes that when a migrant domestic worker, generally women, leaves an abusive situation, the employer will often manoeuvre within the kafala system by informing the police . "If a domestic worker 'runs away', perhaps because her kafeel is abusing her, the kafeel can go to the police station, where she was registered when she arrived to Jordan, and report her as 'missing'. Then, the police will be looking for her."

Hindawi adds that the worker is unlikely to have her passport, as the employer is usually holding it; this provides an additional ground for arrest.

Even NGOs, which are critical in supporting migrant domestic workers, may contribute to further restricting the migrants' freedom. One key issue is that NGOs must protect themselves against criminal charges for "harbouring" a female migrant who has left her kafeel. "Let's say that she [the migrant domestic worker] goes and finds an NGO to help her," Hindawi says; "that NGO will likely take her to a shelter, which offers some domestic workers a place to stay, to make [sure] that they're not harbouring a runaway." However, these migrant shelters will probably advise against the migrant going outside. As Hindawi notes, they do this "out of protection for her. Because now, the employer is looking for her, as well as the police." Unintentionally, and unfortunately, this concern further contributes to restricting the migrant's mobility; she goes from being detained at her employer's house, to being detained in a shelter.

\section{Construction workers: A system of stratification}

\footnotetext{
${ }^{6}$ Jennifer Gordon, "Global Labour Recruitment in a Supply Chain Context," Geneva, International Labour Organization, 2015, available at https://www.ilo.org/global/publications/working-papers/WCMS 377805/lang--en/index.htm [last accessed 26 August 2019].
} 
While domestic workers work for individual families, migrant construction workers are often employed at the bottom of global supply chains. Here, a different set of dynamics contribute to exploitation.

One aspect of migrant vulnerability in the construction sector stems from the way construction workers are recruited and hired for major projects. The Jordanian government assigns the right to hire migrant workers to companies running large construction sites. The law mandates that for each construction project, the government reserves a quota of jobs for Jordanians. For the remaining "unskilled" slots, the law allows contractors to recruit migrants on work permits.

However, the reality is much more complex. Few Jordanians are willing to do manual construction labour for the wages on offer in the country. Yet, employers must fill the Jordanian worker quota. Hindawi reports that "because the contractor is penalised for not recruiting Jordanians, there have been cases where the contractor pays money to some Jordanians but tells [them] 'Stay at home, don't come to work, and here is the salary."' In this situation, even the work set aside for Jordanians is actually done by migrants.

Labour brokers play key roles in filling the construction slots allotted to migrants. Hindawi reports that while labour brokers use some of the work permits assigned to a given project to bring in migrant workers from abroad, they often sell the remainder on the black market. These black market work permits are particularly desirable for migrants who are undocumented, either because they entered the country without authorisation or because they left their kafeel but did not leave the country. They buy visas in order to be able to remain in Jordan and obtain construction positions.

Construction contractors have also been reported to hire migrants who hold permits for work in agriculture, which cost less than those for construction work. This arrangement violates the law but is often overlooked.

Finally, since 2017, Syrian refugees in Jordan have been given access to a separate set of construction work permits that allow them to work for various employers in the industry. Moreover, when Syrians work in the industry without permits, the government does not deport them anymore. "So now," Hindawi points out, "there is a segmented labour market, and a system of stratification, where different groups get different kinds of entitlements."

This combination of migrants and refugees with different statuses at a single worksite creates a situation ripe for abuse. BHRRC ${ }^{7}$ has documented a range of rights violations in the industry in Jordan and elsewhere in the Middle East, ranging from low pay or non-payment of wages to mortally dangerous conditions, rampant discrimination, restrictions on the ability to join a union, and extortion and fraud in the context of recruitment for work.

Migrant construction workers, like their domestic worker counterparts, feel unable to report these problems. Those legally employed with work permits that tie them to the construction

\footnotetext{
${ }^{7}$ Business \& Human Rights Resource Center, "A Human Rights Primer for Business: Understanding Risks to Construction Workers in the Middle East," website, Business \& Human Rights Resource Center, n.d., available at: https://www.business-humanrights.org/en/a-human-rights-primer-for-business-understanding-risks-to-constructionworkers-in-the-middle-east [last accessed 26 August 2019].
} 
contractor know that they will become "illegal" and subject to detention and deportation if they complain and are fired. Migrants who have permits for a sector other than the one they work in are already "illegal," and likewise vulnerable to detention and deportation if they draw attention to themselves. In addition, both may be indebted to labour brokers and/or private recruitment agencies, and fear that if they lose their jobs, they will not be able to pay off their loans and begin sending money home.

\section{Working toward solutions}

Hindawi offers a set of recommendations for reform that would help migrant workers. Overall, Hindawi emphasises the importance of an end to the kafala system; changes to recruitment including an "employer pays" requirement that shifts the costs of migration from the migrant to the sponsor; and better mechanisms for labour law enforcement by the state, as well as for individual redress.

Hindawi also highlights specific initiatives by sector. Turning to domestic workers, Hindawi sees measures to improve the mobility of migrants as crucial. Migrants who face abuse on the job must be able to leave and seek work elsewhere, free of the fear of arrest and deportation. So too, is the creation of a way for domestic workers to pursue legal claims for violations on the job. Other laws will need to change as well: for example, those that put NGOs at risk of prosecution for harbouring when they take in a migrant domestic worker who has left an exploitative situation. Finally, Hindawi notes that it is important to address the individual practices of employers who illegally hold migrants' passports and forbid them from leaving the house. Although these actions violate the law, they are widespread, and the government and advocates need to be innovative in their efforts to challenge their cultural acceptability.

With regard to the construction industry, Hindawi urges attention to the role played by international financial institutions that fund major projects, and the multinational firms that manage and contract out work in Jordan. Hindawi argues that little will change in the treatment of migrant workers in the construction industry in Jordan, until international financial institutions and multinational firms take responsibility for the treatment of migrant workers, who provide the bulk of the labour at the bottom of the construction supply chain. Through BHRRC, Hindawi has conducted a survey ${ }^{8}$ and done corporate research about the 39 major construction projects in Jordan and Lebanon that are funded by international financial institutions. The survey revealed that few had official and publicly available policies protecting the human rights of the workers on their sites, and none appeared to have policies specific to migrant and refugee workers. By contrast, a Human Rights Watch study of the garment industry found "a growing trend" of brands in that industry adopting supply chain transparency policies."

Finally, for all migrant workers, Hindawi emphasises the need for independent and empowered unions and the protection of freedom of association for migrants and refugees; and for the

\footnotetext{
${ }^{8}$ Business \& Human Rights Resource Center, "From Unacceptable Risks to Shared Prosperity: Construction in Jordan \& Lebanon," website, Business \& Human Rights Resource Center, n.d., available at:

https://www.business-humanrights.org/en/jordan-lebanon-construction/from-unacceptable-risks-to-shared-prosperity [last access 26 August 2019].

${ }^{9}$ Human Rights Watch, "Follow the Thread: The Need for Supply Chain Transparency in the Garment and Footwear Industry," website, Human Rights Watch, 2017, available at:

https://www.hrw.org/report/2017/04/20/follow-thread/need-supply-chain-transparency-garment-and-footwear-indust ry [last accessed 26 August 2019].
} 
empowerment of existing NGOs that actively defend migrants' rights at work and advocate for better policies. When migrants have the ability to leave an abusive situation without losing the right to remain in the country, they will be able to join these institutions in the fight for decent work conditions.

\section{Bibliography}

Business \& Human Rights Resource Center, "A Human Rights Primer for Business: Understanding Risks to Construction Workers in the Middle East," website, Business \& Human Rights Resource Center, n.d., available at:

https://www.business-humanrights.org/en/a-human-rights-primer-for-business-understandin g-risks-to-construction-workers-in-the-middle-east [last accessed 26 August 2019].

Business \& Human Rights Resource Center, "From Unacceptable Risks to Shared Prosperity: Construction in Jordan \& Lebanon," website, Business \& Human Rights Resource Center, n.d., available at:

https://www.business-humanrights.org/en/jordan-lebanon-construction/from-unacceptable-ri sks-to-shared-prosperity [last access 26 August 2019].

Daniel Costa and Philip Martin, "Temporary Labor Migration Programs: Governance, Migrant Worker Rights, and Recommendations for the U.N. Global Compact for Migration," website, Economic Policy Institute, August 2018, available at:

https://www.epi.org/publication/temporary-labor-migration-programs-governance-migrant-w orker-rights-and-recommendations-for-the-u-n-global-compact-for-migration/ [last accessed 26 August 2019].

Elizabeth Frantz, “Jordan's Unfree Workforce: State-Sponsored Bonded Labour in the Arab Region,” Journal of Development Studies, 2013, Vol. 49(8), p. 1072-1087, at p. 1077

Jennifer Gordon, “Global Labour Recruitment in a Supply Chain Context,” Geneva, International Labour Organization, 2015, available at https://www.ilo.org/global/publications/working-papers/WCMS 377805/lang--en/index.htm [last accessed 26 August 2019].

Human Rights Watch, "Follow the Thread: The Need for Supply Chain Transparency in the Garment and Footwear Industry," website, Human Rights Watch, 2017, available at: https://www.hrw.org/report/2017/04/20/follow-thread/need-supply-chain-transparency-garm ent-and-footwear-industry [last accessed 26 August 2019].

International Labour Organization "Case Study: Collective Bargaining Agreements in Jordan's Garment Industry,” Geneva, Better Work - International Labour Organisation \& International Finance Corporation, n.d., available at: https://betterwork.org/global/wp-content/uploads/ILO-Better-Work Jordan-Case-Study LR Web.pdf [last accessed 26 August 2019]. 
International Labour Organization, "Migrant Domestic and Garment Workers In Jordan: A Baseline Analysis of Trafficking in Persons and Related Laws and Policies," Geneva, International Labour Office-Fundamental Principles and Rights at Work Branch (FUNDAMENTALS), 2017, available at:

https://www.ilo.org/wcmsp5/groups/public/---ed norm/---declaration/documents/publicatio n/wcms 554812.pdf [last accessed 26 August 2019].

Patti Lenard and Christine Straehle, "Temporary Labour Migration: Exploitation, Tool of Development, or Both?” Policy and Society, 2010, Vol. 29 (4), p. 283-294, at p. 289.

Priyanka Motaparthy, "Understanding Kafala: An Archaic Law at Cross Purposes with Modern Development," Website, Migrant Rights, 2015, available at:

https://www.migrant-rights.org/2015/03/understanding-kafala-an-archaic-law-at-cross-purpo ses-with-modern-development/ [last accessed 26 August 2019]. 